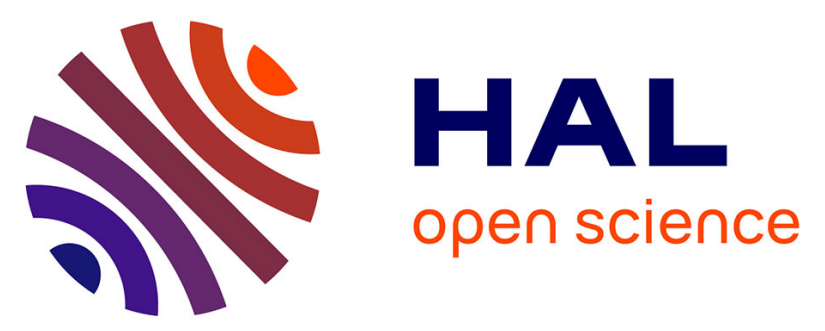

\title{
Bureaucracy, "domesticated" elites, and the abolition of capital punishment. Processes of state-formation and the number of executions in England and Habsburg Austria between 1700 and 1914
}

Dieter Reicher

\section{To cite this version:}

Dieter Reicher. Bureaucracy, "domesticated" elites, and the abolition of capital punishment. Processes of state-formation and the number of executions in England and Habsburg Austria between 1700 and 1914. Crime, Law and Social Change, 2010, 54 (3-4), pp.279-297. 10.1007/s10611-010-9258-1 . hal00637790

\author{
HAL Id: hal-00637790 \\ https://hal.science/hal-00637790
}

Submitted on 3 Nov 2011

HAL is a multi-disciplinary open access archive for the deposit and dissemination of scientific research documents, whether they are published or not. The documents may come from teaching and research institutions in France or abroad, or from public or private research centers.
L'archive ouverte pluridisciplinaire HAL, est destinée au dépôt et à la diffusion de documents scientifiques de niveau recherche, publiés ou non, émanant des établissements d'enseignement et de recherche français ou étrangers, des laboratoires publics ou privés. 
Bureaucracy, "domesticated" elites, and the abolition of capital punishment. Processes of state-formation and the number of executions in England and Habsburg Austria between 1700 and 1914.

\section{Introduction}

The paper argues that rise and decline of capital punishment correlate with long-term processes of state formation. In particular, it stresses that with the introduction of a modern bureaucratic apparatus, the death penalty lost importance for the regime of punishment.

The study is based on two empirical sources: 1) an analysis of the numbers of executions and death sentences in England and in Austria from the eighteenth century to the outbreak of World War I; and 2) English and Austrian pamphlet literature and philosophical treatises on the death penalty in the eighteenth and early nineteenth centuries.

Part 2 of the paper discusses the most important theories concerning the role of capital punishment. It will be shown that the theory of civilizing processes is of particular relevance for understanding the relationship between state-building processes and the decline of cruel forms of punishment.

Part 3 presents a comparison of Austrian and English judicial records. These records provide information about the numbers of executions, the numbers of death sentences and the structure of offences for which capital punishment was imposed. This analysis demonstrates that, as of the second half of the eighteenth century, the death penalty was used much less frequently Austria than in England. This evidence prompts reconsideration of some sociological explanations about the rise and the fall of public executions and the death penalty in general.

Part 4 of the paper focuses on processes of state-formation in both countries. It shows: 1) how institutions of social control differed in the two countries; and 2) how the state-building process in Austria was conducive to reforming the regime of punishment.

Part 5 of the paper presents qualitative analyses of pamphlet literature and philosophical arguments. These help to understand attitudes, affects and emotions related to the death penalty. This analytical approach makes it clear that the main responsibility for a reduction in the use of capital punishment lay with protagonists in high administrative positions of the Habsburg Empire. Their disapproval of capital punishment, as well as the political interests of the absolutistic state, served to weaken local elites. In England, the power figuration was different and therefore bureaucratic institutions did not play the same dominant role. This study demonstrates that capital punishment was a key instrument for the English elites to defend their political and economic privileges.

\section{Some theoretical approaches to explain rise and fall of capital punishment}

Many sociological explanations do not investigate connections between the behavior of the administrative apparatus and changes in the regime of punishment. They are more concerned with the interplay between economic transformations and their influence on social control and punishment (Rusche and Kirchheimer 1939, Melossi and Pavarini 1981, Hay et.al. 1977, Thompson 1975, Polanyi 2001). These authors generally consider state-building processes to be marginal phenomena driven by economic developments. These arguments are summarized 
under the concept of the "political economy of punishment" (Garland 1990: 83-110). Some theorists - including, to a certain extent, Foucault (1975) see modern justice systems reductionistically, as a device to control the lower classes. Most of these theories focus only on certain single case studies, such as Rusche and Kirchheimer (and Marx) on the English or Foucault on the French case (the exception being Melossi and Pavarini who did an international comparison of prison systems). Subsequently, some of these authors have neglected the idiosyncratic character of sociological investigation because they only focus on a single state-society (Weber 1988).

Other theoretical perspectives are more concerned with processes of power formation and their correlation to the regime of punishment; Savelsberg (1999) focuses on the organization of domination and knowledge, while Durkheim stresses the importance of the evolution of institutions and its relationship to the collective conscience (Durkheim 1899/1900: 65-77, Durkheim 1984, 2001, Spitzer 1975). Durkheim suggests studying changes in the regime of punishments within a process of democratization in which the degree of brutality of punishment decreases.

However, it seems that the theory of civilizing processes develops the clearest understanding how the monopolization of a state's power impacts the regime of criminal punishment. On the basis of the Dutch experience, Spierenburg (1984) observed that in the period between the end of the Middle Ages and the second half of the nineteenth century, the use of the death penalty changed dramatically. He formulated three phases of transformation (Spierenburg 1984: 202 - 205). In the first phase, the early modern state sought to assert itself. State authorities attempted to monopolize power and to suppress all alternative forms of private violence. Torture and public executions were the means of demonstrating the state's new power. The early modern states, however, still operated under fairly unstable conditions, and their power institutions were relatively weak. In the second phase, the state's position was more assured, because a mighty power-center developed. During this period, the aristocracy no longer lived under feudal conditions and, thus, no longer had a fundamental military function. The nobility developed a refined life-style and, along with the high bourgeoisie, they were "domesticated" and "pacified". The living conditions of these "domesticated" elites became more elaborate and cultivated. Spierenburg argues that these two elite groups began to rebel against the bloody rituals of punishment first. Their aversion to violence was a result of a process of conscience formation. Their disgust changed into pity. Spierenburg believes that many of these elites entered a "new stage and identified to a certain degree with the convicts on the scaffold" (Spierenburg 1984: 204). In this period, also the torture disappeared. In the third phase, the nation-state was formed. It expanded the capacity for empathy to a wider spectrum, because more social groups were integrated and could participate in power decisions (democratization). Increasingly, democratized power relationships accelerated the moderation of the penal code. Citizens of different social ranks, too, began to identify with each other and with the suffering of the offender on the scaffold. Public executions - and later, executions in general - came to be seen as a source of national shame, and were therefore abolished (see also Evans 1996, Gatrell 1996 with their national focuses on Germany and England). Thus, Spierenburg argues, harsh punishments (like public executions) were the result of wide class differences that caused social and emotional distance. This promoted the unwillingness or impossibility of identification with the destiny of individuals of different (lower) social background. This lack of empathy ultimately caused a lack pity for the culprits on the scaffold.

The theory of civilizing processes demonstrates the importance of three dimensions for the analysis: First, long-term state building-processes are not necessarily economic epiphenomena. They are essential to understanding institutions and organizations of crime control and correction. Second, the evolution of mentality or what is called the habitus (Elias 
1982\&1996, Bourdieu 1989, Wacquant 1990) - as a kind of bodily imprinting of collective long-term experiences - is useful for explaining the role of emotions like pity for criminal offenders). Third, owing to the process of democratization, civilizing standards were extended down the ladder of social hierarchy. The existence of a feeling of national unity seems to support the idea of a downward progression of civilizing standards. Therefore, in the context of this theory, one would most expect the abolition of brutal punishments in democratic nation-states. In democratic societies, citizens more easily identify with the pain of an offender on the scaffold. Thus, they are more likely to avoid public executions - and to eschew capital punishment in general. Some critics of this theory maintain that it is still unclear how empathy and non-violent attitudes spread downward through the social hierarchy from domesticated elites to the rest of the population (Braithwaite 1993).

Another problematic factor is that Spierenburg's work is based on a single case study. This paper shows that the case of the Habsburg Empire does not fit into his patterns of explanation. The Austrian case is quite different from the Dutch or the English experience. The criminal laws of the Habsburg Monarchy were comparatively lenient, despite the fact that it was far from being a democratic nation state, and displayed relatively slow economic development. Under Empress Maria Theresia and the Emperor Joseph II, very progressive reforms were made in the penal system. These reforms included the early introduction of a penitentiary system (Melossi and Pavarini 1981: 71ff), a modern penal code, and a centralized police force. The Habsburg monarchy was also one of the first states to abolish death penalty in the 1780s (although it was reintroduced later, to a greatly reduced extent). Eighteenth- and nineteenth-century England, on the other hand, had established a parliamentary system which evolved (slowly) into a democracy, and the nation exhibited the most advanced economy of its period.

The theory of civilizing processes would suggest that the death penalty would be less prevalent in England than in backward, despotic Austria - yet this was not the case. No other Western European country witnessed such frequent executions as England between 1700 and 1830, a time period during which even many property offences were punished with death. Its penal code was old-fashioned and a modern police force was introduced only at a comparatively late stage. These facts must have some relevance for sociological theories of punishment. They could lend themselves to a Marxian argument focusing only on capitalism and treating state organizations as marginal phenomena. However, the argument made here puts the state- building process in the center. This study compares the development of death penalty in England and in the Austrian Monarchy firstly because these two cases seem to challenge both sociological theories. Furthermore, these cases also help to modify the Elias/Spierenburg theory by revising its themes, in particular the absolutism/democratizationpity nexus, and the role of "domestic elites". Moreover, both cases represent two extreme poles in the handling of state punishment: relatively lenient and harsh. The study also provides a comparative and deeper focus on the two cases. Therefore, it enables one to understand (Weber) certain qualities of the state machinery and subsequently to explain their effects on the regime of punishment. The study highlights two different "cultures of control" (Garland 2001) but also long-term processes of state formation that strongly influenced these cultures.

\section{Numbers of executions and numbers of death sentences in both countries ${ }^{1}$}

\subsection{Death sentences and executions in England}


Before continuing with sociological theory, I will describe the two historical case studies: England and Habsburg Austria from 1700 to the start of World War I. Tables 1 and 2 show clearly that until the middle of the nineteenth century, death sentences and executions were more common in England than in Austria. In the beginning of the nineteenth century, both death sentences and executions were much more common in England than in Austria. Statistical data available for eighteenth century London and Middlesex also indicate bloody penal practices (Gatrell 1996: 616; Reicher 2003: 42). ${ }^{2}$ These data reveal a steady increase in both the number of executions and the number of death sentences, starting with the last decades of the eighteenth century. The numbers peak in the decade after the Napoleonic Wars. Quite similar patterns can be revealed for all of England and Wales. After the 1830's, the numbers of executions and death sentences started to decline, even dipping under the Austrian level, which was much lower for most of the period under study. In England only a small fraction of those who were sentenced to death were hanged. Many condemned convicts were transported to the colonies, which - in many cases - was also fatal. Thus, the English death penalty was part of a larger penal framework that, along with actual executions, included forms of forced labor in the hostile environment of the colonies.

The legal regulation of the death penalty in England changed dramatically in the period between 1700 and 1800. At the beginning of the eighteenth century, just a few crimes were punished by death. At the end of the century, there were more than 200 capital crimes (Radzinowics 1948: 3f, Briggs et al. 1996: 73). Most of the new capital crimes were offences against private property. (For more on the expansion of death penalty during this period, see Thompson 1975, Hay 1977, Gatrell 1996, and Evans 1996). Table 3 shows the important role that offences against private property played in the English penal law. It was not until the 1830 's that the system of penal law began to change and gradually the death penalty was abolished for property offences. However, in the period between 1822 and 1855, only 5 percent of all 17420(!) death sentences in England were imposed for murder - as against 87 percent for offences against private property. Of these last, the vast majority of death sentences were related to nonviolent property crimes.

\subsection{Death sentences and executions in Habsburg Austria}

In seventeenth-century Austria, penal practices were perhaps even crueler than in England. Beside hangings there were many other types of executions (although these were rarely used). However, executions became rare phenomena in eighteenth century Austria, and it seems they were never imposed for property crimes alone (see e.g. the collection of death penalty announcements published in Vienna). ${ }^{3}$ Empress Maria Theresia introduced in the year 1768 a new penal code (the "Constitutio Criminalis Theresiana") which still officially contained numerous brutal penalties such as torture and severe methods of execution (Foregger 1993). However, this new code also marked the beginning of a phase of lasting reforms. In the 1780s, only two decades later, Emperor Joseph II launched major reforms. A new penal code was introduced for some provinces. Most importantly, capital punishment was abolished for all crimes. In some provinces separate reforms were undertaken. The most remarkable and significant of these were the reforms in the 1760s in Tuscany, which introduced a very lenient penal system virtually devoid of capital punishment. In his journey through Tuscany, the English prison reformer Howard counted only 2 executions in 10 years (Melossi and Pavarini 1981: 74f). Grand Duke Pietro Leopoldo, the later Emperor Leopold II, headed this reform movement (which initiated what were known as the Leopoldian reforms) which included figures such as Pietro Verri, Paul Frisi, Cesare Beccaria and others. This group of intellectuals and civil servants from Milan were known as the Caffé. They were tightly 
connected to Viennese circles representing the highest ranks of bureaucrats, such as Counts Kaunitz and Firmian, or enlightened reformers like Josef von Sonnenfels (the author of a famous treatise on the abolition of the torture).

In Austria, capital punishment was embedded in a larger framework of other punishments that developed during the eighteenth century. The oldest and most brutal substitute for executions was forced labor on Venetian galleys. Joseph II introduced the punishment of pulling ships upriver on the Danube as a penalty for severe offenders. The most important development, however, was the introduction of a penitentiary system in eighteenth century which provided an alternative for the death penalty; some early prisons included the Maison de Force in Ghent, or the Plazzo degli Otto and the Stinche in Florence.

During the Napoleonic threat, capital punishment was reintroduced. Its implementation, however, remained at a low level. It was imposed only for murder, offences against the state's authority, and in some cases, for financial fraud in relation to issued stocks (which was considered a threat to the state because it could have endangered the weak economy of early nineteenth century Austria). Beccaria and other reformers held the protection of the state as their highest value. For them, the state was the foundation for protecting all other values.

Therefore, in the period between 1822 and 1855, eight percent of all Austrian death sentences (984) were imposed for offences against the state's authorities (Table 3), which was more than in England. However, the vast majority of all death sentences ( 77 percent) were related to murder. Only a relatively small number were imposed for offences against private property.

Table 1: Death sentences per year and 100,000 inhabitants ${ }^{4}$

\begin{tabular}{ccc} 
Period & England & Austria \\
\hline $1805-1824$ & 6,65 & 0,17 \\
$1825-1844$ & 4,70 & 0,19 \\
$1845-1864$ & 0,28 & 0,29 \\
$1865-1884$ & 0,43 & 1,40 \\
$1885-1904$ & 0,09 & 0,30
\end{tabular}

Table 2: Executions per year and 100,000 inhabitants ${ }^{5}$

\begin{tabular}{ccc} 
Period & England & Austria \\
\hline $1805-1824$ & 0,71 & 0,06 \\
$1825-1844$ & 0,24 & 0,06 \\
$1845-1864$ & 0,06 & 0,03 \\
$1865-1884$ & 0,06 & 0,04 \\
$1885-1904$ & 0,06 & 0,01
\end{tabular}

Table 3: Death sentences and offences against private property $(1822-1855)^{6}$

\begin{tabular}{|c|c|c|c|c|c|c|c|}
\hline & \multicolumn{6}{|c|}{ in percent (rounded) } & \multirow{2}{*}{$\begin{array}{l}\text { abs. } \\
\text { Total }\end{array}$} \\
\hline & $\begin{array}{c}\text { Offences } \\
\text { against } \\
\text { persons }\end{array}$ & $\begin{array}{c}\text { Offences } \\
\text { against priva } \\
\text { property with } \\
\text { violence }\end{array}$ & $\begin{array}{c}\text { Offences } \\
\text { against } \\
\text { private } \\
\text { property } \\
\text { without } \\
\text { violence }\end{array}$ & $\begin{array}{c}\text { Offences } \\
\text { against the } \\
\text { state's } \\
\text { authorities }\end{array}$ & Murder & $\begin{array}{c}\text { other } \\
\text { Offences }\end{array}$ & \\
\hline England & 5 & 17 & 71 & 2 & 3 & 2 & 17420 \\
\hline Austria & 2 & 0 & 13 & 8 & 77 & 0 & 984 \\
\hline
\end{tabular}




\section{Weak and strong states}

The focus on the Habsburg Empire reveals that bureaucracy was the most important institution for uniting a realm that consisted of many divergent provinces. Traditionally, many of these territories - spreading from Italy to Belgium and from the Rhine to the today's Ukraine - did not have much in common. They differed in their political histories as well as in their cultures. In such a situation, the administrative apparatus with its homogeneous staff helped the Viennese power-center, along with its army, to rule over local elites. These local elites stubbornly defended their particular privileges. In many corners of the realm, particular traditional hierarchical systems of ethnic and social dominance prevailed, and the Emperor's power varied throughout his provinces. He was more influential in some areas than in other parts of his realm. As late as 1848, the aristocracy was under the rule of a separate jurisdiction. In particular, the wealthy high aristocracy could not be taxed successfully. Throughout its entire history, the Habsburg Empire neither developed into a single administrative and jurisdictional unit nor did it form a single economic market. It was also far from being a nation-state. This diversity laid down the foundation of the Austrian-Hungarian Monarchy (Doppelmonarchie) in 1867 and thereafter.

The permanent struggle of the Viennese center to overcome this diversity was a typical characteristic of the Habsburg Empire. In the course of the seventeenth and eighteenth centuries, ministries (and their forerunner organizations), local registrar offices, state court systems, police stations, and other offices began to eclipse provincial parliaments and local forms of feudal domination. In Austria, unlike in England, the power game between aristocracy and an absolutist monarch veered slowly in favor of the latter - without, however, ending in a fully centralized state such as France. Austria turned into an Empire consisting of many heterogeneous provinces and ethnic groups and did not develop into a nation-state (which was a barrier for the development of the mutual identification posited by Spierenburg). Aside from the army, the administrative machinery was the most important instrument for governing the realm. A bureaucratic elite began to intervene in all sorts of local affairs - which included matters of criminal justice and crime control. Thus, the Austrian Empire came closer to Max Weber's (1978) type of "bureaucratic domination" than any other Western European state. It cleared a path for the development of modern bureaucracy with its characteristic separation of economic and political/administrative power. In this sense, the Habsburg Monarchy was a strong state.

To speak about weak and strong states implies multidimensional concepts. On the one hand, weakness can refer to a state's military competence. Strong states, in this sense, must have powerful armies and efficient tax systems (which the Habsburg Monarchy did not have). On the other hand, weakness or strength can be linked to the state's ability to cope with internal affairs. There are many reasons why states can be weak in their internal affairs, but strong militarily (such as England). Ruling elites may fear the power of a well-organized police (because they might become a state within the state) and thus tolerate a high crime rate. Such states may be unable to fight crime successfully because, for various reasons, they lack the resources to do so. States may be strong internally because they deploy either armed forces or powerful police organizations to prevent, repress, or detect crime ("policing power"). Secondly, states may make use of social welfare programs to deal with poverty and matters of distribution ("welfare power"). This also may have effects on the regime of crime control and crime treatment, since a class of technocrats produced by the welfare expansion may expand its interests into fields of penal correction and criminology (Garland 1985). Thirdly, a state finally may have a greater or lesser belief that its rule is just and legitimate ("ideological power"). These capacities may coexist in various and idiosyncratic patterns of relationships in every society. All these aspects are reflections of different sorts of social power (Mann 
1986). Although more complex patterns are possible, for the purposes of this paper, I split Mann's category of military power into two parts: external and internal control (policing power).

This paper focuses on the internal weaknesses and strengths because of their relevance to the authorities' belief in their ability to maintain social control. Thus, "strong" refers to the bureaucracy as an internally powerful actor intervening in many spheres of life. Although its proponents may believe in its efficiency, this does not mean that a strong state is necessarily truly efficient. The Austrian bureaucracy was known for being hesitant and slow to react. However, the rule of the administrative machinery (which is the actual meaning of bureaucracy) organized patterns of relationships between the rulers and the ruled population in a totally new way. It differed from a weak-state structure, which is characterized by direct and personal forms of domination. Administrative rule is more distanced than personal rule. Bureaucracy is a form of domination characterized by its indirectness. In theory, it does not involve anything other than professional interests. Above all - because of its impersonal character - bureaucracy is open for new reform projects (sometimes utopian, sometimes realistic).

\section{Structures of state-building: democratization and bureaucracy}

Within the theory of civilizing processes, two lines of argumentation explain the process of de-brutalizating (civilizing) the regime of criminal punishment: the democratization argument and the bureaucracy argument. Spierenburg (1984) and De Swaan (1995 and 1997) stress the importance of "democratization" for civilizing violent attitudes and brutal punishments (democratization argument). They believe that through a process of "functional democratization," the expansion of mutual identification and empathy is promoted. However, within in the framework of the theory of civilizing processes, an alternative explanation for the de-brutalization process of the regime of punishment seems possible. Elias (1982) stresses the argument that in France, after power was monopolized in the hands of the king an administrative apparatus appeared. Elias ends his history of the French civilizing process with the establishment of the royal court. Thus, he does not say much about what happens afterwards. In particular, he does not address the "second civilizing process" which started within the newly founded bureaucracy, and whose protagonists were no longer the nobility, but rather an administrative staff. Yet, it is essential to understand the development of the administrative machinery to see its impact on this "second civilizing process". The bureaucracy argument claims that a strong and self-confident bureaucracy will very likely find alternatives to brutal punishment. They prefer to use modest but permanent repression to maintain social control. The administrative machinery facilitates professionalism, which helps it withstand the economic interests of capitalism and form a new kind of "domestic elite".

When studying the state-building process within the framework of the civilizing process theory, it is important to acknowledge the idiosyncratic characteristics of each state's development. Neither the Austrian nor the English development resembles Spierenburg's subject (the Netherlands) or Elias's subject (France).

\subsection{Patterns of state-building in England}


The Marxian argument about punishment applies well to eighteenth century England. Not until the Glorious Revolution did the English gentry gain control over political and legal institutions. The gentry began to change laws and property rights to serve their own interests. They combined economic and political power and, thus, decreed capital punishment for many sorts of offences against private property (see Thompson 1975).

In England, political and economic power seemed to go hand in hand. However, beginning in the middle of the 1830s, England witnessed political reforms such as new suffrage laws and the introduction of police forces. Before these reforms, the political system was a kind of oligarchy ruled by a powerful land-owning class (the higher nobility and the gentry). The proto-democratic structure of the English political system promoted the death penalty because it linked economic and political interests (as expressed in the high numbers of capital sentences for offences against private property). After the 1830s, the political system was opened up to lower ranks of society. This process of democratization was possible because England, unlike Austria, was a nation-state governed by only one parliament. Here, democratization was intertwined with the process of nation-state building.

England's development in the eighteenth century is surprising, in a certain way. The country became centralized much earlier than most other European countries. The Tudors undertook serious attempts to install a powerful bureaucratic apparatus. The rise of the landowning class's power in the seventeenth century, however, blocked further tendencies towards bureaucratization. After coming to power in the year 1689, the English landowning class resisted attempts to establish strong central organizations such as a police force or a multilayer court system. Many of the state's internal affairs remained in the hands of the local elites and communities. Other tasks that were still in the hands of the state's bureaucracy were "re-localized" (for instance, the abolishing of the famous "Star Chamber"). The English land-owning class feared the power of any central organization. It saw powerful bureaucracies as a threat to its liberties.

Since medieval times, the English court system - unlike many systems in continental states had been centralized and its rules standardized (see Radzinowicz 1948, Beattie 1986). After the Glorious Revolution, however, only the local jury courts remained. All higher courts were abolished. The remaining local courts, therefore, became the centers of the legal system. In the eighteenth and the first half of the nineteenth century, there was no court of appeals. Death sentences were reviewed by the Home Office, and no other institutions existed to review the local courts.

The institutions of public social control were restricted to local elite's influence, too. Thus, Justices of the Peace - an honorary function - were often regarded as clients of the local elites. Edmund Burke, for example, described the JP's as "elderly, greedy, corrupt [men], who had attained office by improper means." (Skyrme 1994: 410). Eighteenth century London experienced some organizations that formed a kind of police, e.g., the "Bow Street Runners", but these organizations were exceptions (Emsley 1996). For the most part, public social work remained the task of volunteers. It was obvious to many that this system allowed only for low-intensity repression and social control to be deployed. However, it was not changed because of the gentry feared of becoming dependent on these police organizations. Therefore, measures of deterrence, especially public hangings, became an important instrument in fighting crime. The fact that the death penalty also became the major punishment for crimes other than murder may be an expression of the helplessness of the English elites in dealing with crime. Many sorts of crimes against private property became punishable by death. Simultaneously, Austria was taking very different steps. 
Unlike in England, Austrian agricultural structure was dominated by patrimonial relationships (see: Kuzmics and Axtmann 2007). Big landowners and powerful peasants were bound by strong obligations to their petty peasantry and farm workers. This circumstance prevented the development of commercialization and the rise of an English-type enclosure movement. The central state administration eagerly tried to narrow the elbowroom of local big landowners, as well. The Habsburgs feared a well organized Gentry. The big landowners were not able to alter property rights in order to subdivide common land among individual owners like in England (Polanyi 2001) because they had no easy access to the law-making process. Both the tight patron-client relationship and the central state intervention established a complicated and indirect system of social control in Austria. Thus, the two fields of economy and politics were separated in many aspects. Already in the course of the seventeenth century, the organized power of the nobility (in parliaments) and the land owning-class was broken up by the monarch and his administration. Unlike its English peers, the Austrian nobility was not able to abolish their small provincial parliaments and to form a common parliament that would oppose the Emperor. Democratization in Austria, therefore, did not take place before the early 1890s.

The Austrian monarchy, on the other hand, developed into a state with a powerful bureaucracy. There was a four-layer court system that had been established in the eighteenth century. Each layer functioned as an appeal court for the layer below. Inquisitional courts based on secrecy that allowed no public access replaced old jury courts. Judges were civil servants and mostly did not have any land-owning origins (Reicher 2003: 127ff), unlike their English counterparts who were recruited from the Gentry up until the end of the nineteenth century (Duman 1975). The legal system in Austria changed systematically so that the ancient common laws of the regions were eventually replaced by a unified penal code. This replacement mainly had the function of reducing the influence of local elites, as Max Weber has described (Weber 1978: 858f).

Policing in Austria changed dramatically toward the end of the eighteenth century. A powerful central police organization began to replace older forms of locally run police forces (Gebhardt 1992). In the early days, the police carried out a multitude of tasks. ${ }^{7}$ In the 1780 s a centrally governed police organization was introduced. The police in the provinces came directly under the control of the Viennese headquarters. Unlike in the case of the later English Bobbies, Austrian authorities attempted to minimize local influence on the police (no local participation). Even the governors of each province - who were directly nominated by the Emperor - did not have any official influence on the provincial police organization. Most importantly, a well-organized secret police was established in the 1780s and 1790s. In the $1850 \mathrm{~s}$, an additional police-organization was introduced in Austria, called the "Gendarmerie", which was a kind of paramilitary force designed for controlling crime in the countryside.

\section{The civilizing process of English and Austrian political elites}

The preliminary results lead one to reconsider the role of "domesticated" elites in eighteenth and nineteenth centuries. The English case may follow the patterns of Spierenburg's study on the Netherlands in some respects (although some noteworthy differences exist as well).

For the English case, pamphlet literature was qualitatively analyzed in order to understand motives and emotions of some protagonists. In the parliamentarian culture of eighteenthcentury England, these pamphlets were intended to influence the public opinion of those who 
had the right to vote. Thus, the pamphlets provide insight on opinions and emotions of the English upper classes and upper-middle classes related to the issue of the death penalty.

For the Austrian case, no such pamphlet literature exists, owing to Austria's absolutist political structure. The opinion of political elites in the Habsburg Empire was formed differently. It was mainly the "enlightened" literature that discussed matters of politics and policing. One example is the work of Joseph von Sonnenfels and especially his treatise against torture. This study, however, only concentrates on the work of Cesare Beccaria, and its influence on the administrative elites of the realm.

In reviewing these sources, two main characteristics become obvious. In the English pamphlet literature, an emotionally distanced attitude prevails towards the lower classes (from which most of the offenders derived). This style of writing is referred to here as "Machiavellian". Quite contrary to the English pamphlet literature, Beccaria's writings often deal with the pain and suffering of offenders on the scaffold. However, his empathy is like that of a father for pain suffered by his children. Beccaria's perspective is not democratic, but from above looking downwards. It resembles the structure of a paternalistic and hierarchical society in which the state and its protagonists lead the citizens (like fathers their children or shepherds their sheep). Therefore, this authorial attitude is referred to here as "paternalistic".

\subsection{Machiavellian attitudes of eighteenth and early nineteenth century English upper classes}

Eighteenth century English pamphlets only rarely give hints of pity and empathy towards the criminals. The content of these pamphlets expresses emotional distance and cold-blooded thinking. Most of the authors were in favor of the death penalty and even of public executions. However, they were neither blind agitators nor fanatics seeking bloody revenge; they were well aware of the pros and cons of public execution, and discussed them openly. They discuss matters of public executions like any other political topic. Examples of this kind of writing are A. Baldwin's "Hanging not punishment enough for Murtherers ..." (1701), Mandville's "An Enquiry into the Cases of the frequent Executions at Tyburn" (1725), and Henry Fielding's "Murders. True Examples of the Imposition of Providences, in the Discovery of Punishment of Murder" (1752). These authors shared some common themes. These were mainly technical - i.e. not moral - problems related to the implementation of the death penalty. They recommended executing fewer people in the future, but not because they felt pity towards the convicts, or they thought it unjust or morally problematic to kill someone. They were more concerned about the deflationary effect of excessive executions. They worried that the many public execution events would diminish the intended purpose of deterrence. For them public executions had transformed into spectacles (see also Gatrell 1996). Thus, Baldwin recommended replacing public hangings with more brutal forms of execution in order to reinstate the effect of deterrence. In his pamphlet, there is no notion of shame in expressing these brutal recommendations. His writings reveal an emotional state that lacks feelings such as pity or abhorrence in relation to capital punishment.

To see underclass criminals as objects rather than as humans of equal standing was an unquestioned attitude. It was the habitus and the Weltanschauung of the gentry. These elite were domesticated in the sense of the theory of civilizing processes. They lived in fine manors, they cultivated an elegant lifestyle, they were well educated, and above all, they established a political system that resolved conflicts relatively peacefully (see: Elias 1960, 18ff).

However, the Machiavellian style of thinking about the poor involved a different aspect of their characters. It stood beside the relatively peaceful attitudes towards their own peers. The 
Machiavellian code towards the lower classes lacks a sense of social responsibility. It reflects the high degree of commercialization in economic relationships that goes along with a lack of responsibility for the poor. This may be a product of the fact that feudal ties were dissolved earlier in England than in parts of Central Europe.

Parliamentary debates about the death penalty reveal similarly distanced emotional patterns standing behind very loose social bonds between the peers and the lower classes. Here, too, it becomes clear that the English elites did not share an empathetic attitude in connection with the many executions. Romilly wrote in his diary:

It is but a few nights ago, that, while I was standing at the bar of the House of Commons, a young man, the brother of a peer, whose name is not worth setting down, came up to me, and breathing in my face the nauseous fun of his undigested debauch, stammered out, "I am against your bill, I am for hanging all ... There is no good done by mercy. They only get worse; I would hang them all up at once." (in: Historical Sketch, 1835: 78f)

Romilly, the great reformer, expressed a different emotional attitude towards the death penalty. He condemned the lack of mercy because he felt pity. Lord Ellenborough, argued differently in his speech at the House of Lords in 1811. He used a tone more refined, and even more Machiavellian. He disguised his lack of pity behind the pretense of defending the little man. This speech was made during a House of Lords debate on a bill to abolish the death penalty for all theft of private property with a value of less than 5 shillings. This bill had already been passed by the House of Commons but was rejected by the Upper House after Ellenborough's speech.

My Lords, if we suffer this bill (as to stealing in shops) to pass, we shall not know where to stand, we shall not know whether we are on our heads or on our feet. If you repeal the Act which inflicts the penalty of death for stealing to the value of five shillings in a shop, you will be called upon next year to repeal a law, which prescribes the penalty of death for stealing five shillings in a dwelling-house, there being no person therein; a law, your lordships must know, on the severity of which, and the application of it, stands the security of every poor cottager who goes out to his daily labour. He, my lords, can leave no one behind to watch his little dwelling ... My Lords, there are cases where mercy and humanity to the few would be injustice and cruelty to the many. There are cases where the law must be applied in all its terrors. My Lords, I think this, above all others, is a law on which so much of the security of mankind depends on execution, that I should deem myself neglectful of my duty to the public if I failed to let the law take its course. (in: Historical Sketch, 1835: 80f)

Lord Ellenborough gave the topic of abolishing the death penalty a certain "spin", implying that abolishing capital punishment for these crimes is even crueler than executing a person. Both statements violate today's standards of political correctness, which would forbid one to speak openly (in the parliament) in such a way about killing people. They also reveal the lack of truly felt pity. Mercy may have played a role amongst some reform-orientated individuals like Samuel Romilly, however, like the majority of political elites, such feelings were less important. They were much too involved in the daily business of defending their economic base. Harsh laws against crimes of poverty were seen as proper measures. 
6.2 Beccaria and paternalistic attitudes of administrative elites in the Habsburg Empire

Let us revise Spierenburg's theme of "domesticated elites" by considering the Austrian case. Here, domesticated elites are identified with high-ranking civil servants and not with nobles or economic upper-classes. For this class of "indifferent middlemen" - usually civil servants - criminal cases were not of personal but professional interest. Their power increased with the rise of the administrative machinery. The peaceful working conditinos of these new elites fostered conditions for the development of a civilized habitus. Bureaucratic leadership helped to establish an "enlightened" regime of crime prevention and crime fighting.

The example of Cesare Beccaria shows the close links between enlightenment and central government. Alongside his philosophical career, Beccaria was a civil servant in a very high administrative position in Habsburg Milan of the eighteenth century. Later, he became involved in reform programs for introducing a modern code of criminal law for the whole of Austria.

"On Crimes and Punishment" became well-known amongst the political leaders of Europe as one of the most famous treatises against the death penalty. The book is more than a detached discussion about the best regime of punishment. It also features passages written in a highly emotional register against the death penalty and other forms of cruel punishments. It is not hard to detect Beccaria's disgust and abhorrence with capital punishment. In some passages Beccaria uses the technique of the internal monologue to demonstrate emotions and empathy with poor criminals. These imaginings were intended to evoke empathy amongst the readers of his treatise.

"What are these laws which I have to obey, which leave such a gulf between me and the rich man? He denies me the penny I beg of him, brushing me off with the demand that I should work, something he knows nothing about. Who made these laws? Rich and powerful men, who have never condescended to visit the filthy hovels of the poor, who have never broken mouldy bread among the innocent cries of starving children and a wife's tears.

[Here, Beccaria uses the rhetoric figure of an anaphora and depicts dramatic scenes of poverty to evoke empathy.]

Let us break these ties, which are pernicious to most people and only useful to a few and idle tyrants; let us attack injustice at its source. [once again an anaphora]

I shall return to my natural state of independence; for a while I shall live free and happy on the fruits of my courage and industry; perhaps the day for suffering and repentance will come, but it will be brief, and I shall have one day of pain for many years of pleasure..." (Beccaria [1764] 2000: 69)

In another passage, Beccaria wrote about the abolition of the death penalty. He described establishing merciful laws in correlation to increasing the central government's power:

How happy humanity would be if laws were being decreed for the first time, now what we see seated on the thrones of Europe benevolent monarchs, inspires of the virtue of peace, of the sciences, of the arts, fathers of their peoples, crowned citizens. Their 
increased power serves the happiness of their subjects because it removes that crueler, because more capricious intermediary despotism, which choked the always sincere desires of the people which are always beneficial when they may approach the throne! If they leave the ancient laws in place, I say, it is because of the endless difficulty of removing the venerated and centuries-old rust. That is a reason for enlightened citizens to wish all the more fervently for their authorities to continue to increase.(Beccaria [1764] 2000: 71f)

Beccaria's "capricious intermediary despotism" resembles our type of weak state and its forms of domination. His opinion on the matter of capital punishment and the penal law is written from a bureaucratic elite perspective. The writings of Beccaria and other "enlightened" philosophers in the Habsburg monarchy were addressed directly against the local elites ("intermediary despotism"). They idealized a state bureaucracy run by a corps of civil servants that simply followed the written law (which itself is an expression of natural law) and that were not involved in local networks. These writers formed the ideological base for Josephian utopianism of the 1780's. Even earlier, the highest administrator of the Habsburg Empire, Graf Kaunitz, wrote a Letter to Graf Firmian, Governor of the Lombardy and direct supervisor of Beccaria. The letter was spurred by Empress Catherine's attempt to lure Beccaria to Russia. Kaunitz wrote:

It would not be desirable for our country to lose a man, who is not only gifted with esprit but who is used to thinking freely. So much of his book [On Crimes and Punishment] enlightens! ... Above all, it would do the ministry credit to honor this genius. We must be sooner than foreign states. (in: Wurzbach 1856: 202) [translation mine]

This letter expresses more than goodwill toward Beccaria's ideas from the highest ranks of the imperial administration. It also reflects that enlightenment philosophers were treated by the royal courts of continental Europe like modern professional football players. It improved the reputation of an "enlightened" ruler to place thinkers like Beccaria among his or her staff. They reflected glory and legitimacy on the leader. This very idea of glory is only to be understood by imagining all absolutist nations of eighteenth century Europe as a network (or as a figuration) within which common symbols of honor and shame are shared by the ruling classes of these states. Unlike in England, the power centers of these states were transformed more and more into an administrative apparatus. Thus, it is no wonder that bureaucrats and rulers began to orientate to each other. They started a process of institutional isomorphism (DiMaggio and Powell 1983). England lay clearly outside this figuration because her leading class differed from continental power-elites.

The introduction of a new court system followed these ideals. First, judges became civil servants bonded to the code of impartiality. Second, an inquisition court-system was introduced (the older jury system was abolished). Third, the new penal code no longer contained torture or the death penalty.

In the late eighteenth century, continental "enlightenment" also symbolized the lifestyle of civil servants who were no longer dependent on local aristocrats' interests. Civil servants lived and worked in salons, bureaus, agencies, universities and other environments in which direct economic involvement played no role. Their social fields, in the sense of Bourdieu 
(Wacquant 1990), demanded professionalism and produced the habitus of distance, selfcontrol, routines, non-violent behavior and the belief in "healing" criminality. These social fields discouraged brutality (as a sort of unprofessional solution to their specific problems), rage and anger in relation to criminals. English upper-class thinkers surely also sought to introduce a rational or "enlightened" order. Lord Byron's statement, however, reveals not so much intellectual as emotional distance to both Beccaria's advice and his world of continental bureaucracy. Byron wrote 1816 from Milan:

I have just heard an anecdote of Beccaria, who published such admirable things on the punishment of death. A soon as his book was out, his servant (having read it, I presume) stole his watch; and his master, while correcting the press of a second edition, did all he could to have him hanged by way of advertisement. (in: Historical Sketch, 1835: 77)

Byron's statement reveals not only that he did not know the local laws - since the 1780's, stealing was no longer punished by death in the Habsburg Empire - but it also clearly indicates spitefulness toward somebody who seems to be a menace for the protection of property.

In England, the reforms of the 1830s promoted an ideal of impartiality, too. However, these reforms were not promoted from "above" (by an enlightened regime) but rather from "below" (from the process of democratization). The English reforms went step by step with the incorporation of new bourgeois and craftsmen classes into the parliamentary system. Thus, in England as in Austria, the death penalty dramatically lost importance due to the process of bureaucratization. However, the two cases showed different patterns of bureaucratization. In Austria the bureaucratization and the abolition of the death penalty resulted from the state's struggle against local elites and patrimonial domination. In England, bureaucratization was a product of democratization.

\section{Conclusion and discussion}

Greenberg and West (2008) have recently focused on the role of democracy, civil rights, and religion in the abolition of the death penalty. This study argues that modern bureaucracy also plays a prominent role in facilitating a lenient regime of punishment. In the case of the Habsburg Empire, the administrative apparatus was mainly responsible for the decline and eventual abolition of capital punishment. Within the state bureaucracy, a "second civilizing process" was initiated. Thus, professional law enforcement specialists, bureaucrats, civil servants, and detached juridical staff formed a new class of "domesticated middlemen elites". In strong states, this new class became a counterweight to other leading groups, especially older economic elites, whose power was based on immediate personal relationships. Out of this new class of bureaucrats a civilizing process was introduced which included the abolition of brutal punishments. On the one hand, the pure logic of bureaucratic routines blocks the involvement of spontaneous emotion while dealing with punishment and social control. On the other hand, peaceful living and working conditions engender disgust and abhorrence towards violence. 
England of eighteenth and early nineteenth centuries combined capitalism, proto-democracy, and a weak state-bureaucracy. Here, the two fields of economic and political power were not yet divorced. They were still overlapping. Office-holders and economic elites (mostly landowners) were highly interrelated. This circumstance led to a situation in which elites claimed they had to rely on brutal punishments in order to fight crime. These elites feared the alternative: a strong state with a powerful police organization. The English case also demonstrates that in such liberal capitalistic oligarchies, only reforms in suffrage rights and further steps of "democratization" laid the foundation for introducing a more lenient penal system. Absolute monarchies did not have the same scruples when introducing authoritarian, non-locally based organizations in order to maintain social control. Here, it was in the interest of the centralized state to weaken local elites.

Increasing the power of the state administration promoted a new habitus of leadership with an attitude against brutal punishments. Another component of this habitus was that private interests should not overlap with professional interests. Crime control became a professional field of work demanding objectivity and emotional distance.

This paper has not examined wider international patterns of the death penalty and the statebuilding process, but it has shown that in some respects, the English and the Dutch cases have similarities that indicate the important role of liberal capitalism, in which economic and political power overlap. However, it is much harder to understand, for example, the case of post-revolutionary France, where the death penalty played a more prominent role than in Austria. It would be also interesting to compare the Austrian case with that of other Empires consisting of many heterogeneous parts. Russia - where Empress Elisabeth abolished the death penalty in 1744 for all crimes, but Catharine II reintroduced it - would be an especially interesting case. 


\section{References}

Beattie, John M. (1986) Crime and the Courts in England 1660-1800. Princeton: Princeton University Press.

Beccaria, Cesare (2000) 'On Crimes and Punishments' and other Writings. (ed.) Richard Bellamy, Cambridge: Cambridge University Press (org.: Dei Delitti e delle pene. 1764).

Bourdieu, Pierre (1989) 'Social Space and Symbolic Power', in: Sociological Theory 7 (1): $14-25$.

Braithwaite, John (1993) 'Shame and Modernity', in: The British Journal of Criminology Vol.33 No.1: 1-18.

Briggs, John et.al. (1996) Crime and Punishment in England. An introductory history. New York: St. Martin's Press.

De Swaan: Abram (1995) 'Widening Circles of Identification: Emotional Concerns in Sociogenetic Perspective', in: Theory, Culture and Society 12: 25-39.

De Swaan, Abram (1997) 'Widening Circles of Disidentification. On the Psycho- and Sociogenesis of the Hatred of Distant Strangers - Reflections on Rwanda', in Theory, Culture and Society 14(2): 105-22.

DiMaggio, Paul J. and Walter W. Powell (1983) 'The Iron Cage Revisited: Institutional Isomorphism and Collective Rationality in Organizational Fields', in: American Sociological Review Vol.48, No: 147-160.

Duman, Daniel (1975) The Judges of England 1730-1875. A Social, Economic, and Institutional History. Dissertation, Baltimore.

Durkheim, Émile (1899/1900) 'Deux Lois de L'Évolution Pénal', in: L'Année Sociologique 4: 65-95 [English: 'Two Laws of Penal Evolution', in: Economy and Society (1973) 2: 285-307].

Durkheim, Émile (1984) The Division of Labor in Society. London 1984.

Elias, Norbert (1960) Nationale Eigentümlichkeiten der englischen öffentlichen Meinung. Vortrag gegeben am 7.Okt. 1960 bei den Hochschulwochen für staatswissenschaftliche Fortbildung in Bad Wildungen (Sonderdruck): Berlin, Zürich: Verlag Max Gehlen.

Elias, Norbert (1982) The Civilizing Process. State Formation and Civilization. Oxford. Basil Blackwell.

Elias, Norbert (1996) The Germans. Power Struggles and the Development of Habitus in the Nineteenth and Twentieth Centuries. Cambridge: Polity Press.

Emsley, Clive (1996) Crime and Society in England, 1750-1900. Second Edition. London \& New York: Longman.

Evans, Richard J. (1996) Rituals of Retribution. Capital Punishment in Germany 1600 1987. Oxford: Oxford University Press.

Foucault, Michel (1975) Surveiller et punir: Naissance de la prison. Paris: Gallimard.

Garland, David (1985) Punishment and Welfare: A History of Penal Strategies. Aldershot: Gower. 
Garland, David (1990) Punishment and Modern Society. A Study in Social Theory. Oxford: Oxford University Press.

Garland, David (2001) The Culture of Control, Crime and Social Order in Contemporary Society. Chicago: University of Chicago Press.

Gatrell, V.A.C. (1996) The Hanging Tree, Execution and the English People 1770 1868. Oxford: Oxford University Press.

Gebhardt, Helmut (1992) Die Grazer Polizei 1786-1850. Ein Beitrag zur Geschichte des österreichischen Sicherheitswesens im aufgeklärten Absolutismus und im Vormärz. Graz: Leykam.

Greenberg, David F. and Valerie West (2008) 'Siting the Death Penalty Internationally', Law \& Social Inquiry, Volume 33, Issue 2: 295-343.

Hay, Douglas et al., ed. (1977) Albion's Fatal Tree. Crime and Society in EighteenthCentury England. Harmondsworth/Middlesex: Peregrine Books.

Kuzmics, Helmut and Roland Axtmann (2007) Authority, State and National Character. The Civilizing Process in Austria and England, 1700-1900. Aldershot: Ashgate.

Mann, Michael (1986) The Sources of Social Power: A History of Power from the begining to A.D. 1760, Volume 1. Cambridge: Cambridge University Press.

Melossi, Dario and Massimo Pavarini (1981) The Prison and the Factory. New Jersey: Barnes\&Noble Books [1977].

Polanyi, Karl (2001) The Great transformation. The Political and Economic Origins of our Time. Boston: Beacon Press.

Radzinowicz, Leon (1948) English Criminal Law and its Administration from 1750. London: Stevens\&Sons.

Reicher, Dieter: Staat (2003) Schafott und Schuldgefühl. Was Staatsaufbau und Todesstrafe miteinander zu tun haben. Opladen: Leske+Budrich.

Rusche, Georg and Otto Kirchheimer (1939) Punishment and Social Structure. New York: Columbia University Press.

Savelsberg, Joachim J. (1999) 'Knowledge, domination and criminal punishment revisited. Incorporating state socialism', Punishment and Society 1, July: 45-70.

Skyrme, Thomas (1994) History of the Justices of the Peace. Exeter: Barry Rose Law Publications.

Spierenburg, Pieter (1984) The Spectacle of Suffering. Executions and the evolution of repression. From a preindustrial metropolis to the European experience. Cambridge: Cambridge University Press.

Spitzer, Steven (1975) 'Punishment and Social Organization: A Study of Durkheim's Theory of Penal Evolution', Law \& Society, Summer: 613-635.

Thompson, E.P. (1975) Whigs and Hunters, The Origin of the Black Act. London: Penguin Books.

Wacquant, Loic (1990) 'Pierre Bourdieu', pp. 215-229 in: R. Stones (ed.) Key Sociological Thinkers. London: Mac Millan.

Weber, Max (1978) Economy and Society. An Outline of Interpretive Sociology. Berkeley \& Los Angeles: University of California Press. 
Weber, Max (1988) Gesammelte Aufsätze zur Wissenschaftslehre. Tübingen: J.C.B. Mohr (Paul Siebeck).

Vienna.

Wurzbach, Constant von (1856) Biographisches Lexikon des Kaisertums Österreich.

Original Sources (historical statistics and records, pamphlets, law books):

Baldwin, A. (1701) Hanging not Punishment enough for Murtherers, High-way Men, and House-Breakers, Offered to be Consideration of the Two Houses of Parliament. London.

Fielding, Henry (1752) Murders. True Examples of the Imposition of Providence, in the Discovery of Punishment of Murder. London.

Foregger, Egmont, ed. (1993) Constitutio Criminalis Theresiana $=$ Römisch-Kaiserl. $z u$ Hungarn and Böheim u.u., Vienna.

Historical Sketch of Reforms in the Criminal Law (From the Law Magazine of February, 1835).

Mandeville, Bernard (1725) An Enquire into the Causes of the frequent Executions at Tyburn. London.

Parliamentary Papers (PP), 1819 - 1901 London.

Statistisches Jahrbuch der österreichischen Monarchie für das Jahr ... (1863-1883).

Tafeln zur Statistik der Österreichischen-Ungarischen Monarchie 1-21 (1828-1848); NF 1-5 (1849-1865).

Todesurteile (Death Penalty Announcements; Collection): aus der Stadt- und Landesbibliothek Wien (Sturminger-Nachlaß), Signature M09B C39975.

\footnotetext{
1 The analysis is based on research in archives and only on primary sources. The Parliamentarian Papers includes annual court statistics and reports about crime and transports to the colonies. The Parliamentary $\underline{\text { Papers }}$ also include some data on the death penalty in eighteenth century London/Middlesex (Parliamentary Papers: VIII 1819, XIX 1826/27). Pamphlet literature from the eighteenth and nineteenth century about executions and capital punishment were found in the British Library. The Austrian statistics are collected in the Tafeln zur Statistik der Österreichischen-Ungarischen Monarchie (Statistical Tables of the Austrian-Hungarian Monarchy) which are also annuals. Some earlier data starting with 1803 was found in Mittermaier (1862: 86). There are also some regional sources which cover periods of the eighteenth century, such as a collection of about 150 published Viennese death sentences starting with 1735.

2 Sources for eighteenth century London: Parliamentarian Papers. London 1819 XVII (1749-1818).

3 Todesurteile (Death Penalty Announcements; Collection): aus der Stadt- und Landesbibliothek Wien (Sturminger-Nachlaß), Signature M09B C39975.

${ }^{4}$ Sources: Parliamentary Papers. London, 1826/27 XIX, 1830/31 XII, 1835 XLV, 1836 XLI, 1837 XLVI, 1839 XXXVIII, 1840 XXXVIII, 1842 XXXII, 1843 XIII, 1846 XXXIV, 1847 XLVII, 1850 XXXVI, 1852/53 LXXXI, 1857 XXXV, 1857/1858 LVII; Tafeln zur Statistik der Österreichischen-Ungarischen Monarchie, Wien, 1828, 1829, 1830, 1831, 1832, 1833, 1834, 1835, 1836, 1837, 1838, 139, 140, 1841, 1842, 1844, 1847 , $1853,1849,1851,1852 / 53 / 54,1855 / 56 / 57$.

${ }^{5}$ Ibid.

${ }^{6}$ Ibid.

7 The Justices of Peace in England were also responsible for a multitude of tasks. They had, for example, to deal with price regulation (Skyrme 1994, Polanyi 2001).
} 